\title{
Prednisolone inhibits phagocytosis by polymorphonuclear leucocytes via steroid receptor mediated events
}

\author{
CAROLYN J.P. JONES, KAREN J. MORRIS, AND \\ MALCOLM I. V. JAYSON \\ From the Rheumatic Diseases Centre, University of Manchester, Hope Hospital, Salford M6 8HD
}

SUMmaRY Prednisolone, at concentrations between $2.78 \times 10^{-6} \mathrm{M}(1 \mu \mathrm{g} / \mathrm{ml})$ and $1.39 \times 10^{-8} \mathrm{M}$ $\left(5 \times 10^{-3} \mu \mathrm{g} / \mathrm{ml}\right)$ exerts an inhibitory effect on the phagocytosis of latex particles by normal human polymorphonuclear leucocytes in vitro as assessed by electron microscopical analysis. This inhibition appears to be receptor-mediated, as it is dependent upon RNA and protein synthesis and is glucocorticoid specific.

It is widely recognised that glucocorticoids are among the most effective anti-inflammatory agents used to treat rheumatoid arthritis, but their precise mode of action is still unknown. It seems likely that one of their prime targets is the polymorphonuclear leucocyte, as specific binding of steroids is exhibited by these cells, ${ }^{1}$ and it has been clearly shown that they are fundamental both to the production of tissue injury and to the acute inflammatory reaction. ${ }^{2}$ Tissue damage is partly caused by the release of lysosomal enzymes following phagocytosis of particles such as immune complexes ${ }^{34}$ and possibly by the formation of toxic metabolites of oxygen $\left(\mathrm{O}_{\varepsilon}{ }^{\circ}\right.$, $\mathrm{OH}^{*}$, and $\mathrm{O}^{\circ}$ ), which have been shown to deploymerise hyaluronate and to degrade synovial fluid. ${ }^{5}{ }^{6}$

The initial step common to inflammatory processes is the phagocytosis of particles. The actions of glucocorticoids on the process of phagocytosis would seem of fundamental importance in understanding the pathogenesis of rheumatoid disease and its control. However, there is little agreement about the effect of glucocorticoids on phagocytosis. In this study we firstly reassessed the effect of prednisolone on particle uptake, and, having demonstrated a significant supression of phagocytosis at therapeutic concentrations, evaluated $(a)$ the role of RNA and. protein synthesis in initiating this effect and $(b)$ the degree of steroid specificity, in order to determine whether or not a glucocorticoid receptor mechanism may be operating.

Accepted for publication 22 January 1982. Correspondence to Dr C. J. P. Jones.
Materials and methods

1. Effect of prednisolone $\left(1 \mu \mathrm{g} / \mathrm{ml}-5 \times 10^{-4} \mu \mathrm{g} / \mathrm{ml}\right)$ on phagocytosis

Leucocytes from heparinised blood taken from 5 healthy male volunteers were isolated by means of dextran sedimentation, and after washing in Dulbecco's modification of Eagle's medium (DMEM) their concentration was adjusted to $10^{7}$ cells per $\mathrm{ml}$. Trypan blue exclusion indicated a viability of over $98 \%$. Serial dilutions of prednisolone (Upjohn) to $10^{-6} \mathrm{mg} / \mathrm{ml}$ were made from a fresh solution of 10 $\mathrm{mg} / \mathrm{ml}$ in absolute alcohol with DMEM as diluent, and alcohol controls matched to each steroid concentration were similarly prepared. $1 \mathrm{ml}$ of cell suspension was incubated with an equal volume of steroid solution or matched alcoholic control at $37^{\circ} \mathrm{C}$ in $5 \% \mathrm{CO}_{2}$ in air for 3 hours 50 minutes. Vials were then transferred to a shaking water bath (160 shakes $/ \mathrm{min}$ ) at $37^{\circ} \mathrm{C}$ and given $100 \mu \mathrm{l}$ of $0.81 \mu \mathrm{m}$ diameter latex particles (Difco) for exactly 10 minutes. Fixation was carried out with aliquots of prewarmed $25 \%$ glutaraldehyde $(0.2 \mathrm{ml})$ and $0.1 \mathrm{M}$ cacodylate buffer, $\mathrm{pH} 7 \cdot 3(1.8 \mathrm{ml})$, which were mixed together immediately before use, and added to the cell suspension to give a final glutaraldehyde concentration of $1.25 \%$. The cells were allowed to fix in suspension for one hour at room temperature and were then spun down and embedded in serum according to the method of Payne and Satterfield. ${ }^{7}$ Pellets were subsequently processed for electron microscopy, embedded in Taab resin, and ultrathin sec- 
tions were examined in a Philips 301 electron microscope. The grids were coded in such a way that specimens were examined blind. Counts of ingested latex particles were performed on 100 randomly selected cells at a screen magnification of $\times 7100$, care being taken to count only those particles surrounded by a complete rim of cytoplasm in order to minimise the inclusion of particles merely adhering to the plasma membrane. Variations in the plane of section could not, however, exclude this possibility completely. Particles were only counted in sections of polymorphonuclear leucocytes (PMNs) which included the nucleus, and degenerate cells were excluded from the count, as were clumps of cells or particles. Examination of material at the ultrastructural level enabled these criteria to be followed with ease. In this initial set of experiments grids were counted once, and the data analysed by the Mann-Whitney $U$ test to obtain a level of significance for each steroid concentration and matched control. The phagocytic index was then calculated

Particles in 100 control cells-particles in 100 test cells

Particles in 100 control cells

and combined data from each dose level were analysed by a Wilcoxon matched pairs signed rank test (Table 1). This experiment was performed 4 times on cells from one of the 5 subjects and twice on cells from another.

The decision to incubate leucocytes in a cell culture medium as opposed to the more commonly used buffered salt solution was based partly on the finding ${ }^{8}$ that amino acids were necessary for any protein synthesis induced by the action of the steroid. Plasma or serum was not included in order to prevent possible interactions by factors such as complement, anticoagulant, or glucocorticoid-binding protein. Pilot studies in our laboratory have since shown, however, that at concentrations of prednisolone of $1 \mu \mathrm{g} / \mathrm{ml}$ the presence of up to $20 \%$ serum, far from diminishing the effect of the steroid, maintained the relative degree of suppression when measured by both Luminol-dependent chemiluminescence and electron microscopy (data not presented), although absolute values of activity were markedly reduced.
2. Effect of protein synthesis blockers on phagocytosis after incubation with prednisolone $\left(5 \times 10^{-1} \mu \mathrm{g} / \mathrm{ml}\right)$ Cells from 3 healthy male volunteers were isolated as above and preincubated in DMEM containing $5 \times$ $10^{-1} \mu \mathrm{g} / \mathrm{ml}$ actinomycin D (Sigma), $1 \mu \mathrm{g} / \mathrm{ml}$ cycloheximide (Sigma), or DMEM alone for 45 minutes before the addition of prednisolone to a final concentration of $5 \times 10^{-1} \mu \mathrm{g} / \mathrm{ml}$ in $0.005 \%$ alcohol, or alcohol alone. After incubation for 3 hours 50 minutes in $5 \% \mathrm{CO}_{2}$ in air at $37^{\circ} \mathrm{C}$, cells were stimulated with latex and processed as described in section 1 above. Each grid was coded and counted twice, unless the range, as calculated by the formula

$$
\frac{\left|x_{1}-x_{2}\right|}{\left(x_{1}+x_{2}\right)} \times 200
$$

where $x_{1}$ and $x_{2}$ are repeat values, was greater than $20 \%$, in which case the count was repeated and all the data pooled to give an average result. (Analysis of the data from section 1 by the Mann-Whitney U test had already demonstrated that a difference of at least $20 \%$ between test and control was necessary before any significant result was evident.) This experiment was performed 8 times, 4 times on one subject, 3 times on another, and once on the remaining subject.

\section{Glucocorticoid specificty}

Cells from 4 healthy male volunteers were isolated as above and incubated in the following steroids at final concentrations of $5 \times 10^{-1}$ and $5 \times 10^{-3} \mu \mathrm{g} / \mathrm{ml}$ and with matched alcoholic controls: prednisolone, dexamethasone, progesterone, oestradiol-17B, and testosterone.* After 3 hours 50 minutes the cells were treated as above. Because 5 sets of data were being compared with each control, control grids were counted 6 times in order to ensure accuracy, and the mean value was taken. Other grids were coded and counted as described in section 2 . This experiment was performed 6 times-twice on 2 subjects and once on 2 others.

\footnotetext{
*Prednisolone: 1,4-pregnadien-11 $\beta, 17 \alpha, 21$-triol-3, 20-dione. Dexamethasone; 1, 4-pregnadien-9-fluoro-16 $\alpha$-methyl-11 $\beta, 17 \alpha$, 21-triol-3, 20-dione. Progesterone; 4-pregnen-3, 20-dione. Oestradiol-17 ; 1,3,5 (10)-estratrien-3, 17 $\beta$-diol. Testosterone; 4-androsten-17 $\beta$-ol-3-one.
}

Table 1 Phagocytosis of latex particles by PMNs: the size of the phagocytic index reflects the degree of inhibition by prednisolone. Results obtained using electron microscopical analysis (EM)

\begin{tabular}{llllr}
\hline $\begin{array}{l}\text { Prednisolone conc. } \\
(\mu \mathrm{g} / \mathrm{ml})\end{array}$ & $\begin{array}{l}\text { No. particles in } 100 \text { cells: } \\
\text { test } \\
\text { Mean } \pm S E\end{array}$ & $\begin{array}{l}\text { No. particles in } 100 \text { cells: } \\
\text { control } \\
\text { Mean } \pm S E\end{array}$ & $n$ & $\begin{array}{l}\text { Phagocytic index } \\
\text { Mean } \pm S E\end{array}$ \\
\hline 1 & $208 \cdot 8 \pm 17 \cdot 2$ & $424 \cdot 3 \pm 69 \cdot 8$ & 9 & $<0 \cdot 005^{*}$ \\
$5 \times 10^{-1}$ & $210 \cdot 8 \pm 21 \cdot 5$ & $446 \cdot 2 \pm 80 \cdot 9$ & 9 & $<0 \cdot 005^{*}$ \\
$5 \times 10^{-2}$ & $262 \cdot 0 \pm 35 \cdot 3$ & $431 \cdot 4 \pm 52 \cdot 8$ & 9 & $<0 \cdot 005^{*}$ \\
$5 \times 10^{-3}$ & $304 \cdot 4 \pm 40 \cdot 3$ & $399 \cdot 2 \pm 43 \cdot 2$ & 9 & $<0 \cdot 005^{*}$ \\
$5 \times 10^{-4}$ & $388 \cdot 7 \pm 47 \cdot 1$ & $438 \cdot 3 \pm 50 \cdot 0$ & 7 & $38 \cdot 3 \pm 5 \cdot 2$ \\
\hline
\end{tabular}

*Very highly significant.

tNot significant. 


\section{Results}

1. Effect of prednisolone $\left(1 \mathrm{\mu g} / \mathrm{ml}-5 \times 10^{-4} \mathrm{\mu g} / \mathrm{ml}\right)$ on phagocytosis

Incubation in 1 and $0.5 \mu \mathrm{g} / \mathrm{ml}$ prednisolone $\left(2 \cdot 78-1.39 \times 10^{-6} \mathrm{M}\right)$ for 4 hours produced marked alterations in the morphology of the majority of polymorphs. Their normally amoeboid forms with slender pseudopodia became rounded with bleb-like protrusions over the surface (Fig. 1.) However, it was thought that this effect could be partly nonspecific, as some of the alcohol controls showed similar results, suggesting that this was the result of the incorporation of a fatty molecule into the plasma membrane of the cells.

At concentrations of prednisolone between 1 $\mu \mathrm{g} / \mathrm{ml}-5 \times 10^{-3} \mu \mathrm{g} / \mathrm{ml}\left(2.78 \times 10^{-6}-1.39 \times 10^{-8}\right.$ M) there was a highly significant reduction $(p<0.005)$ in the ability of polymorphonuclear leucocytes to phagocytose latex particles compared
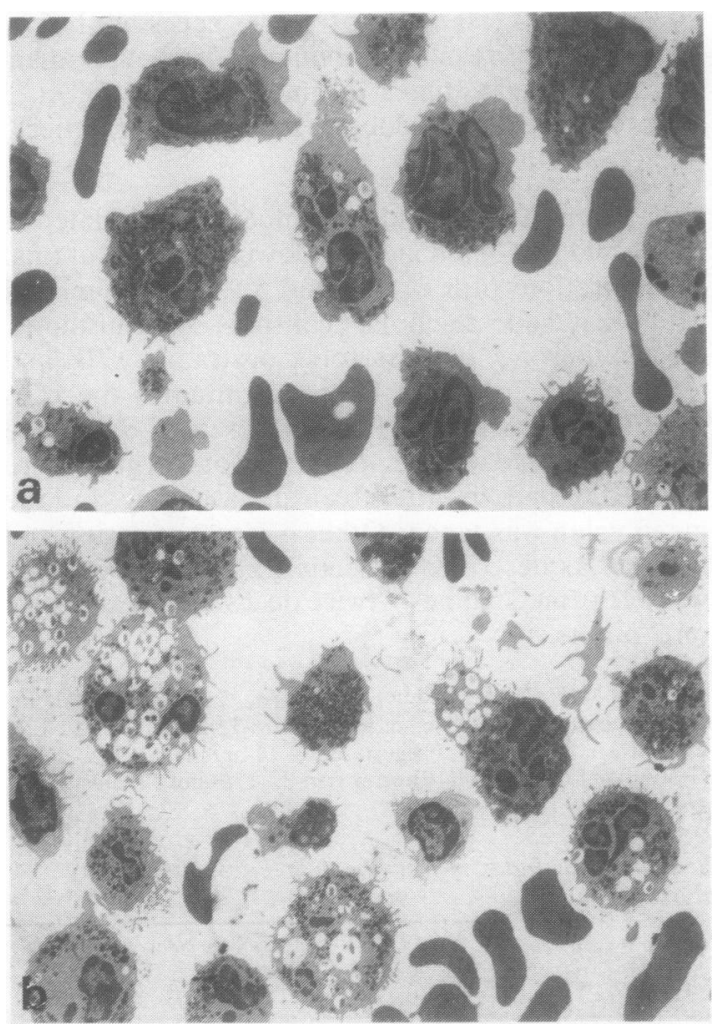

Fig. 1 Electron micrographs showing phagocytosis of latex particles by PMNs after 4 hours' incubation in (a) 0.5 $\mu \mathrm{g} / \mathrm{ml}$ prednisolone in $0.005 \%$ alcohol and (b) $0.005 \%$ alcohol. There is a marked reduction in particle uptake after exposure to the steroid. (Magnification (a) $\times 2125$, (b) $\times 1615$ ). with control preparations (Fig. 1). In 4 experiments maximum suppression occurred at $1 \mu \mathrm{g} / \mathrm{ml}$ prednisolone, in 3 at $5 \times 10^{-1} \mu \mathrm{g} / \mathrm{ml}$, and in 2 experiments $5 \times 10^{-2} \mu \mathrm{g} / \mathrm{ml}$ gave the greatest degree of phagocytic inhibition. Calculation of the mean phagocytic index indicated, however, that $5 \times 10^{-1}$ $\mu \mathrm{g} / \mathrm{ml}$ prednisolone was, overall, the most effective concentration (Table 1). After incubation in steroid-containing media the number of cells devoid of particles was greatly increased. This feature was dose-related, with greatest reduction in uptake occurring in the range $1 \mu \mathrm{g} / \mathrm{ml}-5 \times 10^{-1} \mu \mathrm{g} / \mathrm{ml}$ and decreasing at lower concentrations. Estimation of the phagocytic index confirmed this trend, with the lowest level of prednisolone $\left(5 \times 10^{-4} \mu \mathrm{g} / \mathrm{ml}\right)$ producing a slight stimulation in 2 out of the 7 cases studied. In the subject on whose cells the observations were repeated on 4 separate occasions, although the absolute values were found to vary between experiments, the inhibiting effect of prednisolone within each experiment was found to be comparable. This was also the case in the subject in whom the study was performed twice.

2. Effect of protein synthesis blockers on phagocytosiso after incubation with prednisolone $\left(5 \times 10^{-1} \mathrm{\mu g} / \mathrm{ml}\right.$ ) After 45 minutes' preincubation, followed by 4 hours' coincubation with $5 \times 10^{-1} \mu \mathrm{g} / \mathrm{ml}$ actinomycin? D or $1 \mu \mathrm{g} / \mathrm{ml}$ cycloheximide, the suppressive effect of prednisolone on the phagocytosis of latex particles was almost completely abolished (Fig. 2) and in some cases even produced a slight stimulation of latex particle uptake. With actinomycin D the observed range extended from a suppression of $14.9 \%$ to a stimulation of $21 \cdot 1 \%$ (mean $0 \cdot 2 \%$ stimulation), whereas

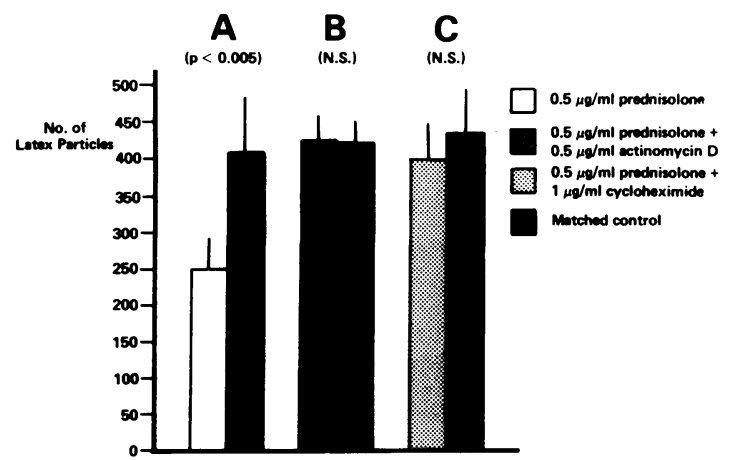

Fig. 2 Histogram showing the effect on latex particle uptake of (a) $0.5 \mu \mathrm{g} / \mathrm{ml}$ prednisolone, (b) $0.5 \mu \mathrm{g} / \mathrm{ml}$ prednisolone $+0.5 \mu \mathrm{g} / \mathrm{ml}$ actinomycin $D$, and (c) 0.5 $\mu \mathrm{g} / \mathrm{ml}$ prednisolone $+1 \mu \mathrm{g} / \mathrm{ml}$ cycloheximide, each with matched controls. Mean $+S E$ of 6 experiments. (NS = not statistically significant by Wilcoxon's matched pairs signed ranks test). 
Table 2 Total particle numbers and phagocytic indices (PI) for the 2 steroid concentrations, obtained in experiments to determine glucocorticoid specificity. Negative values indicate phagocytic stimulation

\begin{tabular}{|c|c|c|c|c|c|c|c|c|c|c|c|}
\hline \multirow{2}{*}{$\begin{array}{l}\text { Steroid } \\
(\mu g / m l)\end{array}$} & \multicolumn{2}{|c|}{ Prednisolone } & \multicolumn{2}{|c|}{ Dexamethasone } & \multicolumn{2}{|c|}{ Progesterone } & \multicolumn{2}{|l|}{ Oestradiol } & \multicolumn{2}{|l|}{ Testosterone } & \multirow{2}{*}{$\begin{array}{l}\text { Control } \\
0.005 \% \\
\text { Ethanol }\end{array}$} \\
\hline & $5 \times 10^{-1}$ & $P I$ & $5 \times 10^{-1}$ & $P I$ & $5 \times 10^{-1}$ & $P I$ & $5 \times 10^{-1}$ & $P I$ & $5 \times 10^{-1}$ & $P I$ & \\
\hline $\begin{array}{l}1 \\
2 \\
3 \\
4 \\
5 \\
6\end{array}$ & $\begin{array}{r}262 \\
222 \\
92 \\
104 \\
448 \\
415\end{array}$ & $\begin{array}{l}39 \cdot 2 \\
43 \cdot 8 \\
56 \cdot 2 \\
34 \cdot 6 \\
31 \cdot 1 \\
41 \cdot 7\end{array}$ & $\begin{array}{l}308 \\
139 \\
175 \\
126 \\
507 \\
468\end{array}$ & $\begin{array}{l}28 \cdot 5 \\
64 \cdot 8 \\
16 \cdot 7 \\
20 \cdot 8 \\
22 \cdot 0 \\
34 \cdot 3\end{array}$ & $\begin{array}{l}503 \\
541 \\
234 \\
296 \\
677 \\
633\end{array}$ & $\begin{array}{c}-16 \cdot 7 \\
-37 \cdot 0 \\
-11 \cdot 4 \\
-86 \cdot 2 \\
-4 \cdot 2 \\
11 \cdot 1\end{array}$ & $\begin{array}{l}466 \\
357 \\
214 \\
272 \\
767 \\
637\end{array}$ & $\begin{array}{r}-8.1 \\
9.6 \\
-1.9 \\
-71.1 \\
-18.0 \\
10.5\end{array}$ & $\begin{array}{l}468 \\
342 \\
213 \\
221 \\
741 \\
590\end{array}$ & $\begin{array}{c}-8.6 \\
13.4 \\
-1.4 \\
-39 \cdot 0 \\
-14 \cdot 0 \\
17 \cdot 1\end{array}$ & $\begin{array}{l}431 \\
395 \\
210 \\
159 \\
650 \\
712\end{array}$ \\
\hline Significance $(p)^{*}$ & $<0.025$ & & $<0.025$ & & NS & & NS & & NS & & \\
\hline Donor & $5 \times 10^{-3}$ & $P I$ & $5 \times 10^{-3}$ & $P I$ & $5 \times 10^{-3}$ & $P I$ & $5 \times 10^{-3}$ & $P I$ & $5 \times 10^{-3}$ & $P I$ & $\begin{array}{l}0.00005 \% \\
\text { Ethanol }\end{array}$ \\
\hline $\begin{array}{l}1 \\
2 \\
3 \\
4 \\
5 \\
6\end{array}$ & $\begin{array}{l}351 \\
349 \\
133 \\
119 \\
603 \\
279\end{array}$ & $\begin{array}{r}8.8 \\
-28 \cdot 8 \\
26.1 \\
55.9 \\
25 \cdot 4 \\
31.4\end{array}$ & $\begin{array}{l}231 \\
199 \\
125 \\
177 \\
447 \\
360\end{array}$ & $\begin{array}{l}40 \cdot 0 \\
26 \cdot 6 \\
30 \cdot 6 \\
34 \cdot 4 \\
44 \cdot 7 \\
11 \cdot 5\end{array}$ & $\begin{array}{l}578 \\
401 \\
190 \\
276 \\
735 \\
465\end{array}$ & $\begin{array}{r}-50 \cdot 1 \\
-48 \cdot 0 \\
-5 \cdot 6 \\
-2 \cdot 2 \\
9 \cdot 0 \\
-14 \cdot 3\end{array}$ & $\begin{array}{l}479 \\
312 \\
152 \\
211 \\
825 \\
417\end{array}$ & $\begin{array}{c}-24 \cdot 4 \\
-15 \cdot 1 \\
15 \cdot 6 \\
21 \cdot 9 \\
-2 \cdot 1 \\
-2 \cdot 5\end{array}$ & $\begin{array}{l}419 \\
386 \\
200 \\
243 \\
782 \\
479\end{array}$ & $\begin{array}{r}-8 \cdot 8 \\
-42 \cdot 2 \\
-11 \cdot 1 \\
10 \cdot 0 \\
3 \cdot 2 \\
-17 \cdot 7\end{array}$ & $\begin{array}{l}385 \\
271 \\
180 \\
270 \\
808 \\
407\end{array}$ \\
\hline Significance $(p)^{*}$ & NS & & $<0.025$ & & NS & & NS & & NS & & \\
\hline
\end{tabular}

*Significance as assessed by steroid versus control values using Wilcoxon's matched pairs signed ranks test. NS = not significant.

with cycloheximide the effect was slightly less marked, the range varying between $27.4 \%$ inhibition and $6.8 \%$ stimulation (mean $8.4 \%$ suppression). Prednisolone alone showed a suppressive effect on phagocytosis ranging from $27 \cdot 4 \%$ to $59 \cdot 8 \%$ (mean $39 \%)$, which was very highly significant $(p<0.005)$ when analysed by the Wilcoxon's matched pairs
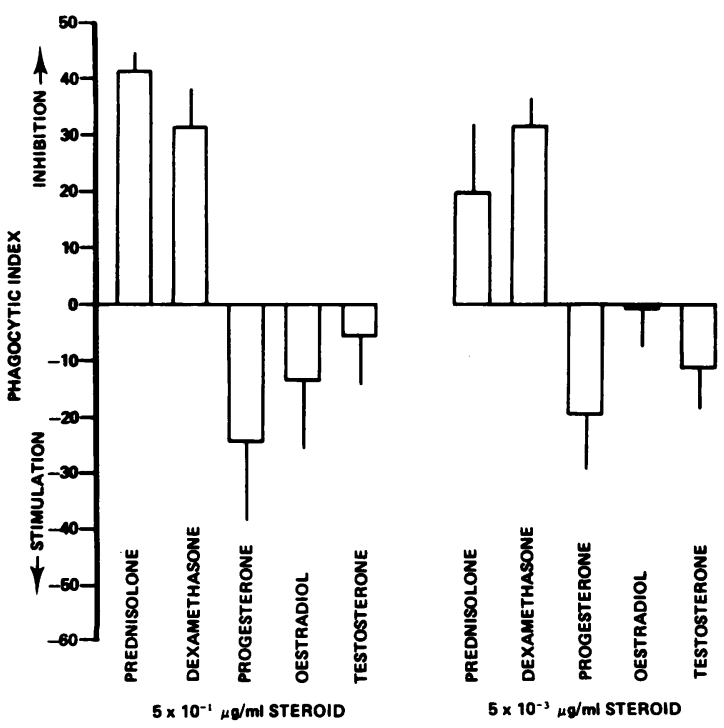

Fig. 3 Histogram showing relative degrees of inhibition (prednisolone and dexamethasone) and stimulation (progesterone, oestradiol, testosterone) of phagocytosis using a range of steroids. Mean $+S E$ of phagocytic indices from 6 experiments. signed ranks test. Results after incubation with the protein synthesis blockers were not statistically significant.

\section{Glucocorticoid specificity}

Prednisolone and dexamethasone showed a marked inhibitory effect on latex particle uptake at the higher concentration of $5 \times 10^{-1} \mu \mathrm{g} / \mathrm{ml}$, which was statistically significant $(p<0.025)$ when analysed by Wilcoxon's matched pairs signed rank test. Dexamethasone also gave a significant degree of inhibition $(p<0.025)$ at the lower steroid concentration. However, there was no overall significant difference between test and control preparations with progesterone, oestradiol or testosterone, and in many instances these substances were markedly stimulatory, though results varied between experiments (Table 2). The greatest degree of inhibition found was $21.9 \%$, with oestradiol, but it was only one of 2 results that showed suppression out of the 6 experiments performed. The phagocytic indices were calculated, and the mean plus standard error of the 6 experiments for each steroid has been plotted (Fig. 3) to show the overall effect on phagocytosis.

\section{Discussion}

Clinical experience has shown that, in the treatment of rheumatoid arthritis, glucocorticoids will suppress joint inflammation, and there is some evidence to suggest that they will delay progressive destructive changes. ${ }^{9}$ They must, however, be administered judiciously, as continued treatment increases the risk of osteoporosis, liability to infection, sodium reten- 
tion, and pituitary-adrenal suppression and other side effects. The development of a steroid which possesses anti-inflammatory properties without these undesirable side effects has not yet been achieved, and in order to attain this it is first necessary to establish the means whereby the steroids exert their anti-inflammatory effect.

Our results clearly demonstrate an inhibitory action by prednisolone on the phagocytic capacity of polymorphonuclear leucocytes at concentrations between $1 \mu \mathrm{g} / \mathrm{ml}$ and $5 \times 10^{-3} \mu \mathrm{g} / \mathrm{ml}\left(2.78 \times 10^{-6}\right.$ $\left.\mathrm{M}-1.39 \times 10^{-8} \mathrm{M}\right)$, which covers the range of total prednisolone plasma levels found in patients receiving long-term prednisone therapy ${ }^{10}$ and contrasts with earlier studies ${ }^{11-13}$ which failed to show a reduction in phagocytosis except at concentrations of glucocorticoid at least 3 orders of magnitude greater than those used in this study. These findings have also been confirmed by us using Luminol-dependent chemiluminescence. ${ }^{14}$

Opinion has so far been divided on the effect of glucocorticoids on phagocytosis. Some workers have reported a marked inhibition of particle uptake in vitro $^{11-131516}$ and in vivo, ${ }^{17}$ whereas others have failed to show an effect either clinically ${ }^{18} 19$ or experimentally. ${ }^{20}{ }^{21}$ These differences may in part be explained by the fact that different investigators have employed different steroid preparations possessing, as we have found, different potency of action. The majority of studies have used water-soluble ester forms of the steroid (hemisuccinate, acetate, or phosphate), whereas our own pilot experiments showed (data not presented) that prednisolone sodium succinate required an equivalent of a 1000 -fold increase in concentration to produce a level of inhibition of phagocytosis comparable to that produced by $5 \times 10^{-2} \mu \mathrm{g} / \mathrm{ml}$ prednisolone. Other workers ${ }^{22}$ have found that the ester form of hydrocortisone required a 20 -fold increase in concentration to obtain the same result as the pure steroid. It is possible that the polymorphonuclear leucocyte is not capable of splitting off the succinate group which is normally removed in the liver by an esterase ${ }^{23}$ but that with high concentrations of steroids in the ester form there is enough of the free substance to be effective. We have also found by time-course experiments (data not presented) that an incubation period of 3 hours is required to obtain the maximum degree of suppression of phagocytosis by $0.5 \mu \mathrm{g} / \mathrm{ml}$ prednisolone. Even after one hour's incubation there is a barely significant difference between test and control populations $(p=0.07)$ when results are examined by the Mann-Whitney $U$ test. This lag period may explain the failure of some previous studies, using short incubation times, ${ }^{20}{ }^{21}$ to demonstrate an effect of glucocorticoids on phagocytosis.
The inhibition of phagocytosis which we have described is clearly glucocorticoid-specific, steroids other than prednisolone and dexamethasone often producing a stimulation in particle uptake. Oestradiol at a concentration of $5 \times 10^{-3} \mu \mathrm{g} / \mathrm{ml}$ gave the lowest mean value of the phagocytic index, and, although some claims have been made for an antiinflammatory property of natural and synthetic oestrogens, ${ }^{24-26}$ phagocytosis itself has been variously reported to be suppressed, ${ }^{27}$ unaffected ${ }^{28}$ or slightly stimulated. ${ }^{29}{ }^{30}$ Progesterone has no glucocorticoid activity, though it competes with glucocorticoids for receptor binding. ${ }^{31}$ As in our study, it has been shown to stimulate phagocytosis ${ }^{30}$ and to increase subsequent pyrogen release,$^{32}$ while testosterone and oestrone impart resistence to mice after experimental bacterial infection, suggesting more efficient phagocytosis.

The abolition of the steroid-induced suppression of phagocytosis after treatment with actinomycin D (an inhibitor of RNA but not protein biosynthesis) and cycloheximide (an inhibitor of protein biosynthesis) together with the restriction of this action to glucocorticoids, strongly implies that prednisolone is operating via classical steroid receptor-mediated events. ${ }^{33}$ Under these conditions specific binding of steroids to cytoplasmic receptors and their subsero quent translocation to the nucleus is followed by an? alteration in transcriptional-translational processes and the production of new messenger RNA. This initiates the biosynthesis of the specific protein(s) causing the particular cellular response. Our data are therefore consistent with the suggestion that prednisolone initiates the biosynthesis of some protein or polypeptide which prevents the cell from phagocytosing normally.

Although the precise site of action remains unclear, it has been shown in earlier studies that anti-inflammatory steroids can prevent prostaglandin generation by inducing the biosynthesis of one or more proteins with approximate molecular weights of 30 000-40 000 daltons, which can block the activity of phospholipase $A_{2}$ in neutrophils. ${ }^{34}{ }^{35}$ As in our study, the development of this inhibition is dependent upon RNA and protein synthesis and can be prevented by the action of actinomycin $D$ and cycloheximide. Phospholipase $\mathrm{A}_{2}$ cleaves arachidonic acid from membrane phospholipids, and glucocorticoids are thought to act by inhibiting the availability of this substrate, therefore reducing levels of the lipoxygenase and cyclo-oxygenase metabolites of arachidonic acid such as prostaglandins, leukotrienes, and thromboxanes, all of which are potent mediators of inflammation. ${ }^{36}$ The production of toxic oxygen moieties which are released as by-products of both prostaglandin and leukotriene 
biosynthesis, and which have such harmful cellular effects as DNA denaturation and the inactivation of enzymes,${ }^{37}$ would also be reduced by phospholipase inhibition. It is possible that a similar inhibition of phospholipase $\mathbf{A}_{2}$ activity may be responsible for the failure of phagocytosis seen in this study, by reducing the availability of membrane precursors necessary for the biosynthesis of new plasma membrane which must be formed to accomodate ingested particles. ${ }^{38}$ However, failure of phagocytosis may also be due to a malfunction of the cytoskeleton (microtubules and microfilaments), the plasma membrane, or the relationship between the two. ${ }^{39}$ Although Crabtree and co-workers ${ }^{40}$ have described a marked reduction in the number of $F c$ receptors per cell after treatment with dexamethasone, our experimental system contained no plasma proteins or antibodies, and the uptake of latex particles was independent of Fc receptors. Ingestion of particles is, however, an active energy dependent event, inhibited by metabolic poisons and requiring glycolysis and glycogenesis to proceed ${ }^{39}$ and it has been reported that glucocorticoids inhibit ATP generation ${ }^{41}$ and interfere with glucose transport. ${ }^{42}$

Phagocytosis itself causes the release of prostaglandins, leukotrienes, free radicals, and lysosomal enzymes, ${ }^{353}$ which can affect such diverse functions as cell migration and aggregation, hexose transport, intracellular levels of guanosine $3^{\prime}: 5^{\prime}$-cyclic monophosphate (cyclic GMP) and calcium influx. ${ }^{36}$ Lysosomal enzymes of polymorphonuclear leucocytes include those capable of degrading both proteoglycan ${ }^{44}$ and collagen.$^{45}$ It is apparent, therefore, that any reduction in phagocytosis, be it a direct or indirect effect of glucocorticoid action, is of vital importance in ameliorating the inflammatory process and allowing a period of recovery to begin.

We wish thank Dr S. B. Lucas and his staff, Department of Medical Computation, University of Manchester for assistance with the statistical analyses, and Dr M. K. Jasani of Ciba Geigy Pharmaceuticals Division for helpful advice.

Dr C. J. P. Jones is supported by the Dr Hadwen Trust for Humane Research to whom we are most grateful.

\section{References}

1 Sloman J C, Bell P A. Glucocorticoids and myeloid leukaemia. In: Bell P A, Borthwich N M, eds. Glucocorticoid Action in Leukaemia. Cardiff: Alpha Omega Publishing, 1979: 161-9.

2 DeShazo C V, Henson P M, Cochrane C G. Acute immunologic arthritis in rabbits. J Clin Invest 1971; 51: 50-7.

3 Weissmann G, Zurier R B, Hoffstein S. Leukocytic proteases and the immunologic release of lysosomal enzymes. Am J Pathol 1972; 68: 539-64.

4 Henson P. Mechanisms of release of granule enzymes from human neutrophils phagocytosing aggregated immunoglobulin. Arthritis Rheum 1973; 16: 208-16.
5 McCord J M, Wong K. Phagocyte-produced free radicals: role in cytotoxicity and inflammation. In: Fitzsimons D W, ed. Oxygen Free Radicals and Tissue Damage. Ciba-Geigy Foundation Symposium 65 (new series), 1979: 343-51.

6 Greenwald R A, Moy W W. Effect of oxygen-derived free radicals on hyaluronic acid. Arthritis Rheum 1980; 23: 455-63.

7 Payne C M, Satterfield V F. A simple procedure for the preparation of rosetted cells for electron microscopy. J Clin Pathol 1980; 33: 505-8.

8 Danon A, Assouline G. Inhibition of prostaglandin biosynthesis by corticosteroids requires RNA and protein synthesis. Nature 1978; 273: 552-4.

9 Medical Research Council and Nuffield Foundation Report. A comparison of prednisolone with aspirin and other analgesics in the treatment of rheumatoid arthritis. Ann Rheum Dis 1960; 19: 331-7.

10 Wagner J G, Wexler D, Agabeyoglu I T, Bergstrom R F, Sakmar E, Kay D R. Plasma protein-binding parameters of prednisolone in immune disease patients receiving long-term prednisone therapy. J Lab Clin Med 1981; 97: 487-501.

11 Greendyke R M, Bradley E M, Swisher S N. Studies of the effects of administration of ACTH and adrenal corticosteroids on erythrophagocytosis. J Clin Invest 1965; 44: 746-53.

12 Olds J W, Reed W P, Eberle B, Kisch A L. Corticosteroids, serum, and phagocytosis: in vitro and in vivo studies. Infect Immun 1974; 9: 524-9.

13 Smith R J. Phagocytic release of lysosomal enzymes from guinea-pig neutrophils-regulation by corticosteroids, autonomic neurohormones and cyclic nucleotides. Biochem Pharmacol 1977; 25: 2001-9.

14 Jones C J P, Morris K J, Jayson M I V. The effect of prednisolone on phagocytosis by human polymorphonuclear leucocytes (PMNs). Ann Rheum Dis in press.

15 Cooper M R, DeChatelet L R, McCall C E. The in vitro effect of steroids on polymorphonuclear leucocyte metabolism. Proc Soc Exp Biol Med 1972; 141: 986-90.

16 Fuenfer M M, Olsen G E, Polk H C. Effect of various corticosteroids upon the phagocytic bactericidal activity of neutrophils. Surgery 1975; 78: 27-33.

17 Jessop J D, Vernon-Roberts B, Harris J. Effects of gold salts and prednisolone on inflammatory cells. 1 . Phagocytic activity of macrophages and polymorphs in inflammatory exudates studied by a 'skin-window' technique in rheumatoid and control patients. Ann Rheum Dis 1973; 32: 294-300.

18 Clarke J R, Gagnon R F, Gotch F M, et al. The effects of prednisolone in leucocyte function in man. A double-blind controlled study. Clin Exp Immunol 1977; 28: 292-301.

19 Skeel R T, Yankee R A, Henderson E S. Hexose monophosphate shunt activity of circulating phagocytes in acute lymphoblastic leukemia. J Lab Clin Med 1971; 77: 975-84.

20 Mandell G L, Rubin W, Hook E W. The effect of an NADH oxidase inhibitor (hydrocortisone) on polymorphonuclear leukocyte bactericidal activity. J Clin Invest 1970; 49: 1381-8.

21 Losito A, Gwyn Williams D, Cooke G, Harris L. The effects on polymorphonuclear leukocyte function of prednisolone, and azathioprine in vivo and prednisolone, azathioprine and 6-mercaptophrine in vitro. Clin Exp Immunol 1978; 32: 423-8.

22 Chretien J H, Garagusi V F. Corticosteroid effect on phagocytosis and NBT reduction by human polymorphonuclear neutrophils. J Reticuloendothel Soc 1972; 11: 358-67.

23 Nugent C A, Eiknes K, Tyler F H. A comparative study of the metabolism of hydrocortisone and prednisolone. JClin Endocrinol 1959; 19: 526-34.

24 Mueller M N, Kappas A. Estrogen pharmacology. (2). Suppression of experimental immune polyarthritis. Proc Soc Exp Biol Med 1964; 117: 845-7. 
25 Lerner L J, Carminati P, Schiatti P. Correlation of anti-inflammatory activity with inhibition of prostaglandin synthesis activity of non-steroidal anti-estrogens and estrogens. Proc Soc Exp Biol Med 1975; 148: 329-32.

26 Blackwell G J, Flower R J, Nijkamp F B, Vane J R. Phospholipase $\mathrm{A}_{2}$ activity of guinea-pig isolated perfused lungs: stimulation and inhibition by anti-inflammatory steroids. Br J Pharmacol 1978; 62: 79-89.

27 Toivanen P. Enhancement of staphylococcal infection in mice by estrogens. Ann Med Exp Biol Fenn 1967; 45: 136-46.

28 Bodel P, Dillard G M, Kaplan S S, Malawista S E. The anti-inflammatory actions of estradiol on human leukocytes. J Lab Clin Med 1972; 80: 373-84.

29 Von Haam E, Rosenfeld I. The effect of the various sex hormones upon experimental pneumococcus infections in mice. J Infect Dis 1942; 70: 243-7.

30 Nicol T, Vernon-Roberts B, Quantock D C. The influence of various hormones on the reticulo-endothelial system: endocrine control of body defence. J Endocrinol 1965; 33: 365-83.

31 Werb Z, Foley R, Munck A. Interaction of glucocorticoids with macrophages. Identification of glucocorticoid receptors in monocytes and macrophages. J Exp Med 1978; 147: 1684-94.

32 Dillard G M, Bodel P. Studies on steroid fever. (2). Pyrogenic and anti-pyrogenic activity in vitro of some endogenous steroids of man. J Clin Invest 1970; 49: 2418-26.

33 Thompson E B, Lippman M E. Mechanism of action of glucocorticoids. Metabolism 1974; 23: 159-202.

34 Flower $\mathbf{R}$ J, Blackwell $\mathbf{G}$ J. Anti-inflammatory steroids induce biosynthesis of a phospholipidase $A_{2}$ inhibitor which prevents prostaglandin generation. Nature 1979; 278: 456-9.

35 Hirata F, Schiffmann E, Venkatasubramanian K-M, Solomon D, Axelrod J. A phospholipase $\mathbf{A}_{2}$ inhibitory protein in rabbit neutrophils induced by glucocorticoids. Proc Natl Acad Sci USA 1980; 77: 2533-6.

36 Goetzl E J. Oxygenation products of arachidonic acid as mediators of hypersensitivity and inflammation. Med Clin North Am 1981; 65: 809-28.

37 Metz S A. Anti-inflammatory agents as inhibitors of prostaglandin synthesis in man. Med Clin North Am 1981; 65: 713-57.

38 Elsbach P. Lipid metabolism by phagocytes. Semin Hematol 1972; 9: 227-39.

39 Stossel T P. Phagocytosis (part 2). N Engl J Med 1974; 290: 774-80.

40 Crabtree G R, Gillis S, Smith K A, Munck A. Mechanisms of glucocorticoid-induced immunosuppression: inhibitory effects on expression of Fc receptors and production of T-cell growth factor. J Steroid Biochem 1980; 12: 445-9.

41 Young D A. Glucocorticoid action on rat thymus cells: interrelationships between carbohydrate protein and adenine nucleotide metabolism and cortisol effects on these functions in vitro. J. Biol Chem 1969; 244: 2210-7.

42 Munck A. Metabolic site and time course of cortisol action on glucose uptake, lactic acid output, and glucose-6-phosphate levels of rat thymus cells in vitro. J Biol Chem 1968; 243: $1039-42$.

43 Claesson H-E, Lundberg U, Malmsten C. Serum-coated zymosan stimulates the synthesis of leukotriene $B_{4}$ in human polymorphonuclear leukocytes. Inhibition by cyclic AMP. Biochem Biophys Res Commun 1981; 99: 1230-7.

44 Oronsky A L, Ignarro L J, Perper R J. Release of cartilage mucopholysaccharide-degrading neutral protease from human leukocytes. J Exp Med 1973; 138: 461-72.

45 Robertson P B, Ryel R B, Taylor R E, Shyu K WFullmer H M. Collagenase: localization in polymorphonuclear leukocyte granules in the rabbit. Science 1972; 177: 64-5. 